\title{
A newly recorded neogregarine (Protozoa, Apicomplexa), parasite in honey bees (Apis mellifera) and bumble bees (Bombus spp)
}

\author{
JJ Lipa 1, O Triggiani 2 \\ 1 Institute of Plant Protection, Miczurina 20, 60-318 Poznan, Poland; \\ 2 Istituto di Entomologia Agraria, Universita degli Studi, via Amendola 165/A, 70126 Bari, Italy
}

(Received 10 February 1992; accepted 31 August 1992)

\begin{abstract}
Summary - A new infectious disease of Apis mellifera, Bombus hortorum and B terrestris is reported to be caused by a parasitic protozoan belonging to the order Neogregarinida. The disease can be diagnosed based on the presence of characteristic navicular spores measuring 11.4-14.4 $\mathrm{x}$ 3.6-5.4 $\mu \mathrm{m}$. Infection level in host populations was low but since this parasite was found in host insects in Finland and ltaly, it evidently has a wide distribution in Europe.
\end{abstract}

Apis / Bombus / neogregarine / protozoan / parasite

While continuing our studies (Lipa and Triggiani, 1988; Triggiani, 1991) on spiroplasma, flagellate and microsporidian infections of the honey bee (Apis mellifera L) and bumble bees (Bombus spp) in some adults collected in Italy and in Finland very peculiar spores were observed which could not be attributed to known pathogens of these beneficial insects. A preliminary report is therefore presented to alert researchers in various countries as to the occurrence and incidence of the pathogen involved.

The new pathogen was first noticed in 1988 in flying workers and queens of Bombus hortorum $\mathrm{L}$ and $B$ terrestris $\mathrm{L}$ collected by sweep net from various crops in Apuglia (southern Italy). When the same pathogen was also recorded in 1990 in one $A$ mellifera worker from a hive in the experimental apiary at the Agricultural Research Center in Jokionen, Finland, it was concluded that the pathogen was a new parasitic protozoan which, based on the type of spores and the life cycle, belongs to the order Neogregarinida.

The detailed data on host, country and locality records in which the new pathogen was noted are given in table I. These data indicate that the infection level by this neogregarine is very low, which is not surprising as infections of the honey bee ( $A$ mellifera) by eugregarines (Stejskal, 1965) or flagellates (Langridge, 1966) are also generally at a very low level and have been reported from very few localities. However, 
Table I. Host and localities in which a new neogregarine infection was observed.

Host and locality $\begin{gathered}\text { No of } \\ \text { insects } \\ \text { examined infects } \\ \text { infected }\end{gathered}$

\section{Bombus hortorum}

Carpino, Italy; 2 May 1988

Massafra, Italy; 23 May 1988

$\begin{array}{rr}17 & 1 \\ 3 & 1\end{array}$

\section{Bombus terrestris}

Lesina, Italy; 17 Feb 1988

Policoro, Italy; 20 Feb 1988

Massafra, Italy; 23 Feb 1988

$33 \quad 1^{1}$

$34 \quad 1^{2}$

$30 \quad 2^{1}$

\section{Apis mellifera}

Jokioinen, Finland; 23 July 199034 since this parasitic neogregarine was found in Finland and Italy we assume that it has a wide distribution in Europe and that a thorough survey may indicate that it also occurs in other countries or continents.

The following diagnostic features may be helpful in survey and identification of the pathogen involved. On smeared fat body preparations of $A$ mellifera and Bombus spp, various developmental stages were observed. Micronuclear meronts contain up to 40 nuclei and have a diameter of up to $45 \mu \mathrm{m}$ (fig 1). Micronuclear merozoites are oval or elongated in shape and measure 5-9 × 2.5-3.5 $\mu \mathrm{m}$ (fig 1).

Macronuclear meronts measure $20 \times 15$ $\mu \mathrm{m}$ and give rise to ovoid or pyriform macronuclear merozoites 5-8 $\mu \mathrm{m}$ in diameter (figs 1,2).

The spores observed in Apis and Bombus were identical. They are navicular in
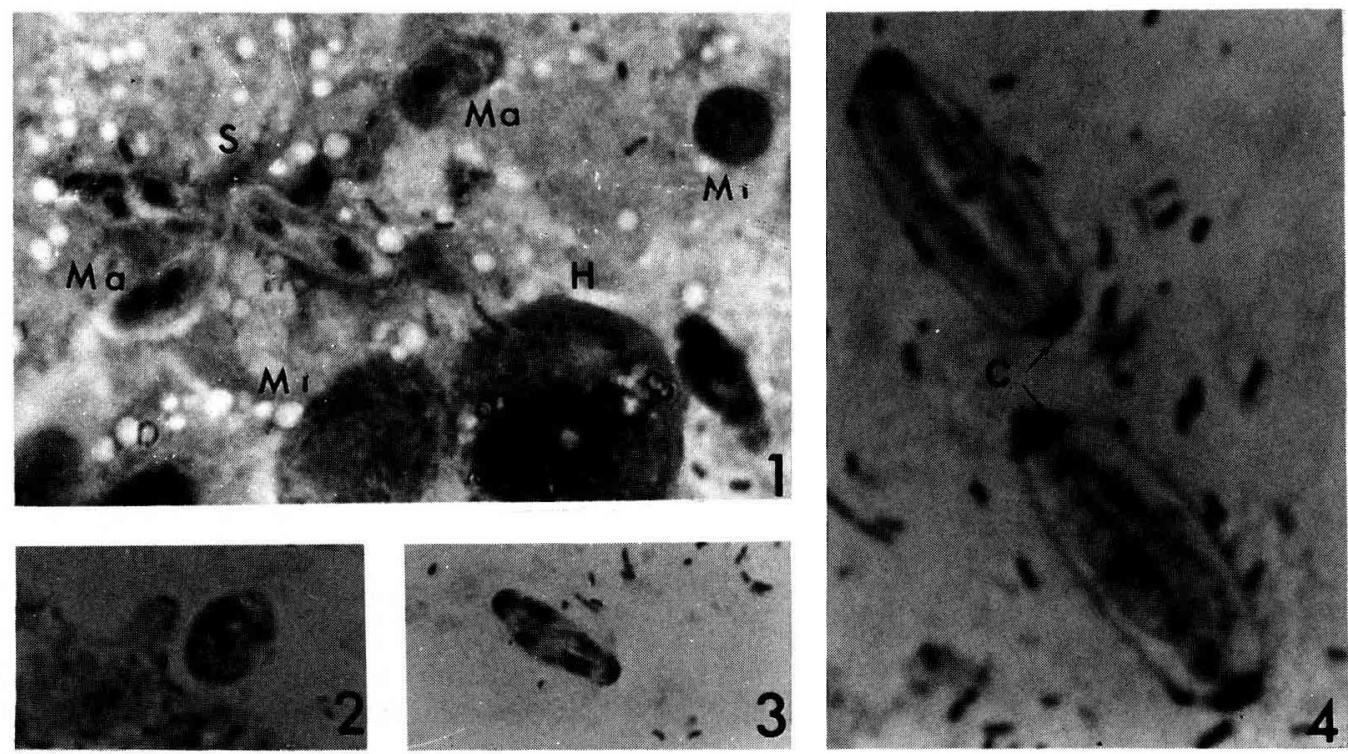

Figs 1-4. Developmental stages of a parasitic neogregarine. 1. Spores (S), micronuclear (Mi) meronts, macronuclear (Ma) merozoites (Ma), and honey bee (A mellifera) hemocyte (H); x523. 2. Binucleate macronuclear merozoite in smeared tissues of $B$ terrestris; $x 435$. 3. Young spore with 4 visible uninucleate sporozoites; $x 348$. 4. Two mature spores from $A$ mellifera, with clearly visible polar caps (C) and enigmatic sporozoites; $x 1800$. 
shape, and have distinct caps (figs 3,4). Spores fixed in methanol for $2 \mathrm{~min}$ and stained with $0.25 \%$ Giemsa for $15 \mathrm{~h}$ are 11.1-14.4 $\mu \mathrm{m}$ long and 3.6-5.4 $\mu \mathrm{m}$ wide. Inside the stained young spores 4 uninucleate sporozoites are readily visible (fig 3); however, they become less visible in the mature spores (fig 4).

The life cycle and morphology of meronts and spores indicate that the protozoan infecting $A$ mellifera and Bombus spp belongs to the order Neogregarinida (= Schizogregarinida) (Apicomplexa). Its spores (sporocysts) differ greatly from those of presently known genera as they contain only 4 sporozoites while spores of the genera eg Mattesia, Farinocystis or Syncystis contain 8 sporozoites. In addition, the spores of this newly reported neogregarine are narrow and have a delicate wall. All these features indicate that this neogregarine constitutes both a new species and a new genus. It also represents the first record of neogregarine infection in the Apidae.

\section{ACKNOWLEDGMENTS}

The senior author (JJL) expresses his thanks to the National Research Council for Agriculture and Forestry of the Academy of Finland for providing funds to conduct a study in Finland (June-October, 1990) and to the University of Bari for support in conducting this study in Italy (December 1990).

Résumé - Un nouveau parasite néogrégarine (Protozoa, Apicomplexa) de l'abeille (Apis mellifera) et du bourdon (Bombus sp) (Hymenoptera, Apidae). L'examen au microscope de tissus d'adultes d'Apis mellifera, récoltés en 1990 en Finlande, et de Bombus terrestris et de $B$ hortorum, récoltés en 1988 en Italie, a montré la présence de spores d'un protozoaire encore inconnu. D'après le cycle de développement du parasite, étudié sur des frottis du corps gras fixés 2 min au méthanol et colorés avec une solution de Giemsa à $0,25 \%$ durant $8-12 \mathrm{~h}$, le parasite appartient à l'ordre des Neogregarinida. Les mérontes macronucléaires renferment jusqu'à 40 noyaux, leur diamètre atteint $45 \mu \mathrm{m}$. lls mesurent $20 \times 15 \mu \mathrm{m}$ et donnent naissance à des mérozoïtes macronucléaires (ma) ovoïdes ou pyriformes ayant un diamètre de 5-8 $\mu \mathrm{m}$ (figs 1-2). Les mérozoïtes micronucléaires sont de forme ovale ou allongée et mesurent 5-9 x 2,5-3,5 $\mu \mathrm{m}$ (fig 1). Les spores observées chez Apis et chez Bombus étaient identiques. Elles sont naviculaires et possèdent des chapeaux distincts aux 2 extrémités. Les spores fixées et colorées ont 11,1-14,4 $\mu \mathrm{m}$ de long et $3,6-5,4 \mu \mathrm{m}$ de large. À l'intérieur des spores colorées on peut facilement reconnaître 4 sporozoïtes contenant chacun un noyau (fig 3). La morphologie des premiers stades de développement et les caractéristiques morphologiques des spores différencient ce nouveau néogrégarine des genres Mattesia et Farinocystis. Nous considérons donc que le néogregarine découvert chez Apis et Bombus est un genre nouveau et une espèce nouvelle. Comme le montre le tableau I, le niveau d'infestation dans les colonies d'abeilles et de bourdons étudiées était relativement faible. Néanmoins l'intensité de l'infestation chez certains individus parasités était très forte. Ceci prouve que le pathogène peut diminuer les processus vitaux et les activités des hôtes parasités. Sa répartition géographique est étendue puisqu'on l'a trouvé aussi bien en Finlande qu'en Italie.

\section{Zusammentassung - Ein neu beschrie- benes neogregarines parasitisches Pro- tozoon bei Apis mellifera und Bombus sp. Die mikroskopische Untersuchungen von 1990 in Finnland gesammelten $A$ mel- lifera-Arbeiterinnen und von Bombus terre- stris und $B$ hortorum, die 1988 in Italien ge-}


sammelt worden waren, ergab den Befund von Sporen eines bisher unbekannten parasitischen Einzellers. Der Lebenszyklus des Parasiten, untersucht an Ausstrichen des Fettkörpers (2 min fixiert in Methanol und gefärbt in $0.25 \%$ Giemsa-Lösung für 8-12 h) bewies, daß er zur Ordnung der Neogregarinida gehört. Macronucleäre Meronten enthalten bis zu 40 Nuclei und besitzen einen Durchmesser von bis zu 45 $\mu \mathrm{m}$. Micronucleäre Merozyten sind oval oder länglich und messen 5-9 × 2.5-3.5 $\mu \mathrm{m}$ (Abb 1). Macronucleäre Meronten messen $20 \times 15 \mu \mathrm{m}$ und erzeugen ovoidale oder birnenförmige macronucleäre Merozyten (ma) mit einem Durchmesser von 5-8 $\mu \mathrm{m}$ (Abb 1-2).

Die bei Apis und Bombus beobachteten Sporen (Oozysten) waren gleich. Sie haben die Form eines Bootes und tragen an beiden Enden deutliche Kappen. Fixierte und gefärbte Sporen sind 11.1-14.4 $\mu \mathrm{m}$ lang und 3.6-5.4 $\mu \mathrm{m}$ breit. Im Inneren der gefärbten Sporen sind deutlich vier Sporozoiten mit je einem einzigen Kern zu sehen (Abb 3).

Die Morphologie der frühen Entwicklungsstadien und morphologische Merkmale der Sporen unterscheiden diese neu beschriebene Protozoe von den Gattungen Mattesia und Farinocystis. Deshalb betrachten wir die von uns bei Apis und Bombus neu beschriebene Neogregarine als neue Gattung und neue Art.
Wie aus Tabelle I zu ersehen, ist der Infektionsgrad bei den untersuchten Bienenvölkern und Hummelkolonien relativ niedrig. Dennoch war die Intensität der Infektion bei einigen erkrankten Tieren ziemlich hoch und dies beweist, daß der Erreger die Lebensvorgänge und die Aktivitäten der befallenen Wirte beeinträchtigen kann. Der Erreger hat offensichtlich eine weite geographische Verbreitung, da er sowohl in Finland wie in Italien beobachtet wurde.

Parasitologie / Protozoa / Neogregarinida / Apis / Bombus

\section{REFERENCES}

Langridge DP (1986) Flagellated protozoa (Fam Trypanosomatidae) in the honey bee, Apis mellifera in Australia. J Invertebr Pathol 8, 124-126

Lipa JJ, Triggiani O (1988) Crithidia bombi sp n, a new flagellated parasite of a bumble bee Bombus terrestris L (Hymenoptera, Apidae). Acta Protozool 27, 287-290

Stejskal M (1965) Acuta rousseaui n sp, $\mathrm{n}$ gen, $\mathrm{n}$ fam, eine neue cephaline Eugregarine, Parasit der Honigbiene. Bull Apic 8, 217-225

Triggiani $O$ (1991) Micro e macroganismi endozoici in adulti di Bombus Latr e Psithyrus Lep (Hymenoptera: Apidae). Atti XVI Congr Nazionale Italiano di Entomologia (Bari-Martina Franca 23-28 September 1991) 587-597 